DOI: 10.20472/IAC.2018.036.025

BIKIKA LALOO

NORTH EASTERN HILL UNIVERSITY, India

\title{
IT WORKS! WHATSAPP AS A SUPPLEMENTARY TEACHING TOOL IN HIGHER EDUCATION : A STUDY OF LIBRARY AND INFORMATION SCIENCE EDUCATION IN MEGHALAYA, INDIA
}

\begin{abstract}
:
That Social Networking Sites (SNS) or Social Media are pervading people's lives all over the world is well established by now. Apart from their manifold uses and abuses, SNS are also playing a significant role in academia, where a variety of groups have been formed for a variety of purposes. University Faculty are experimenting with Whatsapp as a supplementary tool for connecting with their students to enhance subject knowledge, to counsel and to promote a feeling of belongingness. This study explored the significance and value of Whatsapp groups initiated for four papers in the Department of Library and Information Science, North Eastern Hill University, Shillong, Meghalaya, India. The Whatsapp questionnaire that was shared in the respective groups generated data that confirm the significance of Whatsapp groups as supplementary tools for teaching and also as important spaces for holistic development of students
\end{abstract}

\section{Keywords:}

Social Networking Sites; Whatsapp Groups; Higher Education; Teaching Methods; Library and Information Science Education 


\section{Significance of Whatsapp groups in higher education}

Competent teachers the world over are evolving creatures who, while being firmly rooted in tradition are also forever looking for ways and means to improve themselves and their profession. Part of this includes grasping the latest trends in their profession to enhance their existing skills and keep the interest of their students alive. The social media phenomenon that has hit mankind like a tsunami is also making its presence felt in education. Facebook, Whatsapp, Instagram, Twitter and their ilk are smart phone applications meant for social interaction and are being mined in higher education for their attractive features (textual and audio visual) and constant availability. They are ideal tools for engaging students and can supplement classroom lessons. As far as their significance is concerned, some random points emerge

- They bring together teachers and students scattered all over, geographical boundaries notwithstanding.

- $\quad$ They are healthy spaces for sharing of news, views and ideas

They evoke a sense of belongingness

They help draw out timid members

Apart from the above benefits, Whatsapp also ensures more privacy than the other social media and is thus an ideal tool in academia.

\section{Testimonies from the literature}

That social media are fast becoming relevant as teaching tools in higher education has been testified by the literature ((Calvo, Arbiol \& Iglesias, 2014). Their uses include : nurturing the social atmosphere; creating dialogue and encouraging sharing among students; and as a learning platform.

The benefits of Whatsapp as a supplementary tool in higher education include simple operation, low cost, availability, and immediacy. The educational advantages include the creation of a pleasant environment and an in-depth acquaintance with fellow students, which had a positive influence upon the manner of conversation. Academic advantages such as the accessibility of learning materials, teacher availability, and the continuation of learning beyond class hours are also mentioned. (Bouhnik, D., \& Deshen, M., 2014). Usage of different platforms of Social Media between faculty and class reveals the following: potential for learning enhancement (Smit, 2012); potential for learners to be active in their studies (Cifuentes \& Lents, 2011); informal communication between students (Cifuentes \& Lents,2011; Smit, 2012); in-person interaction between students 
and faculty related to course con-tent and personal issues (Cifuentes \& Lents,2011); sense of belonging and community (Doering, Lewis, Veletsianos, \& Nichols-Besel, 2008; Sweeny, 2010

However as with every other media, here too problems exist. Bouhnik and Deshen (2014) have mentioned issues like the technical difficulty that not all high school students possess a Smartphone. Secondly, teachers are apt to be annoyed by the flood of irrelevant and nonsensical messages. Also, educational difficulties may arise, such as incompatibility of language between students and the students' assumptions that their teachers should be available

\section{Using Whatsapp groups as supplementary tools for teaching : A teacher's} initiative - Having been fruitful within the framework of the physical classroom for almost twenty years of her service (in the Department of Library and Information Science, North Eastern Hill University, Meghalaya, India) the researcher, a social media user herself realized the potential of Whatsapp groups for engaging her students beyond the classroom. The intention was to use social media to evoke more interest in the papers that she is teaching and in the library profession itself, to develop a sense of belonging amongst the students and to draw the timid ones out of their shells.

The idea was suggested to the students, all of who readily agreed to join the groups. Class representatives of each class were requested to start the groups which would include the teacher (this researcher) and all students. Group members were requested to keep the content appropriate and to use the English language, as members spoke and understood different Indian languages.

\section{The Groups}

First Semester MLibSc for Paper 104 - Information Sources and Services

Third Semester MLibSc for Paper 303 - Collection Development

Interns

PhD Scholars 


\section{Types of information shared}

The types of information shared in all four groups are similar. Often, the same information is shared in all groups, either by the teacher or the students. Information includes both text and audio visual.

Textual information includes news on DLIS, NEHU semester results, NET results, results of interviews held anywhere in India, (especially in the North East of India), announcements on conferences, seminars and workshops. Links to informative articles on libraries and librarianship, greetings on teachers' day, librarians day, birthdays, new year, religious festivals. Congratulatory messages on new appointments, success at examinations and even weddings and births. There are even obituaries included in the groups. One of the advantages of these groups is the possibility of members meeting and sharing information even during holidays, curfews and bandhs (general strikes especially by non-governmental organizations where towns are closed own).

Audio/Visual information includes audio talks, video talks, films, cartoons etc. 


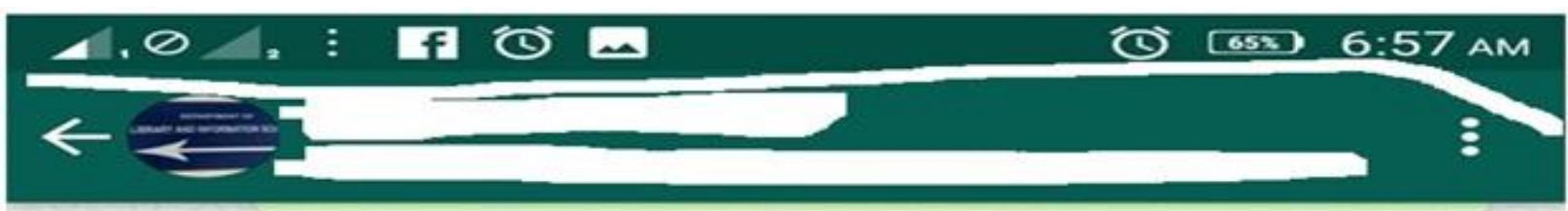

A BIG CONGRATULATIONS to each one of you for finally receiving your results and passing

Fruits of hard work. Praise God $7: 45 \mathrm{PM} \sim$

Special CONGRATULATIONS to Well done.

Thank u ma'am 7:47 PM

Random advice _ Next step _ NET. 7:47 PM $\checkmark$ Also start applying for jobs.

7:47 PM

OK ma'am. 7:49 PM

All the very best in this journey called life. It won't be easy but it can be beautiful. God be with each one of you.

Figure 1: Congratulatory and counseling messages 


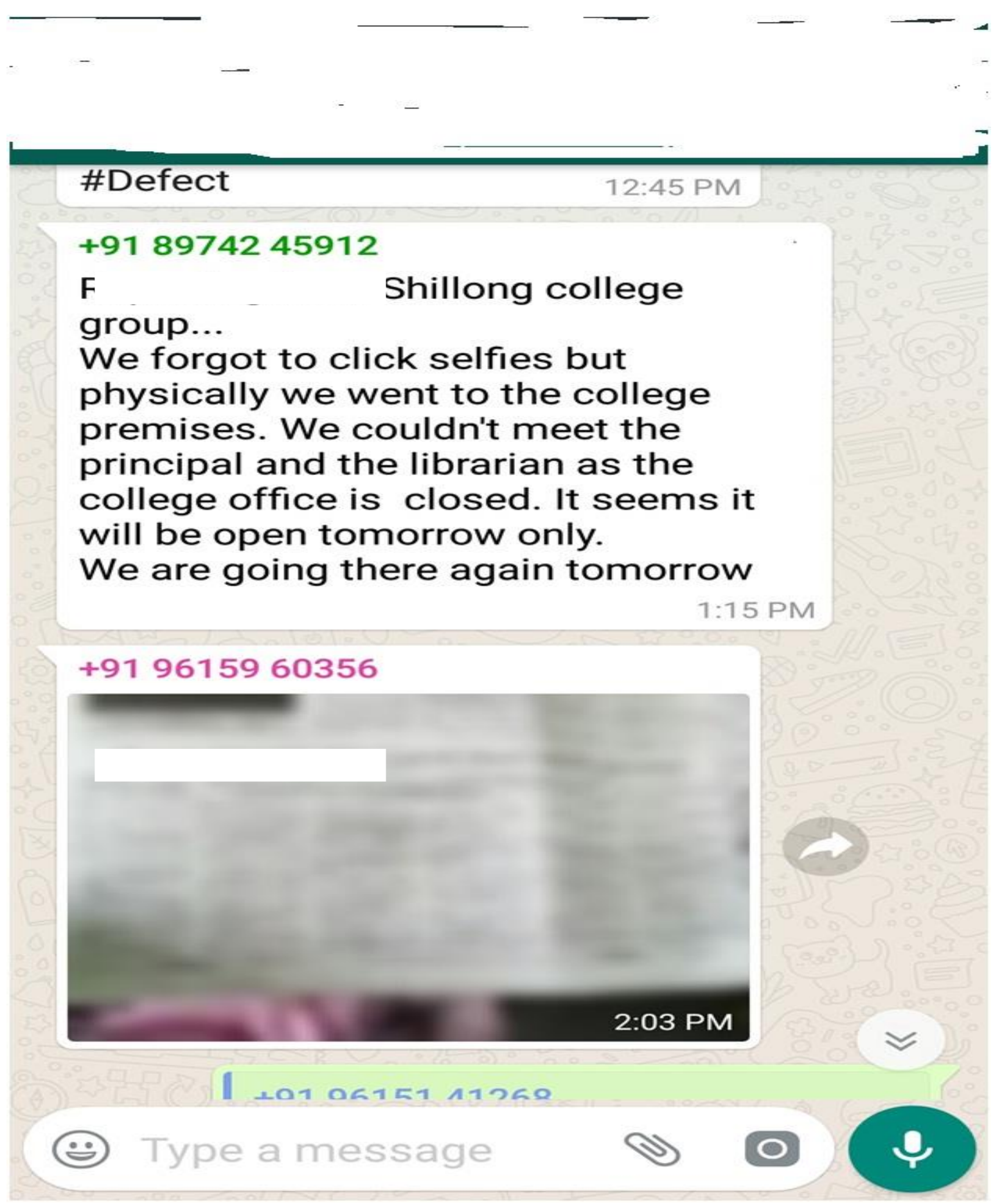

Figure 2: Interaction on Internship 


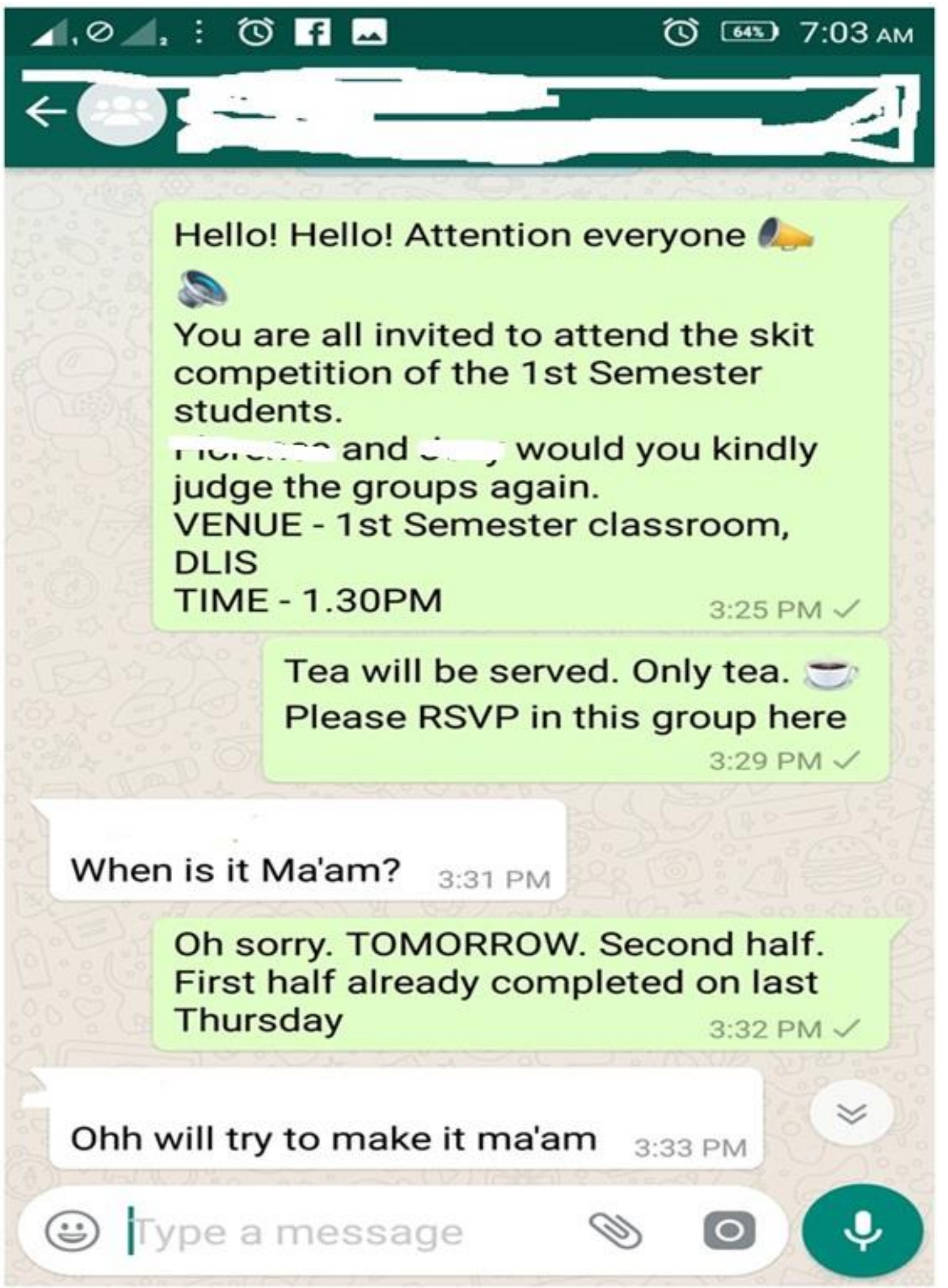

Figure 3: Announcement 
You

Types of libraries to be presented

Roll numbers 1 - 10 =Public library

Ma'am what does method for obtaining source means?

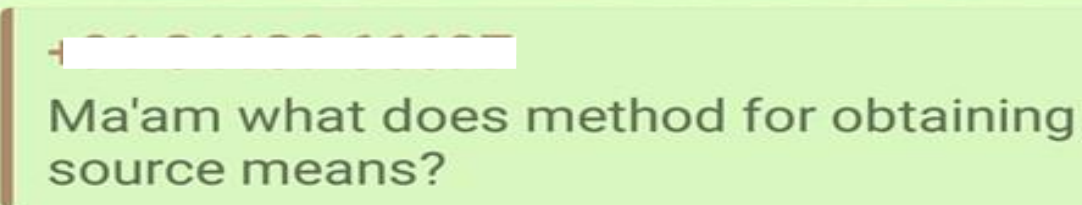

Obtaining

Through purchase

Through subscription

Through exchange

Through gifts

Through membership of associations

9:19 PM $\checkmark$

$+$

You

Obtaining

Through purchase

Through subscription

Thank you ma'am 9.19 PM

() Type a message

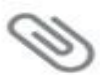

Figure 4: Teacher-Student discussion on a topic 


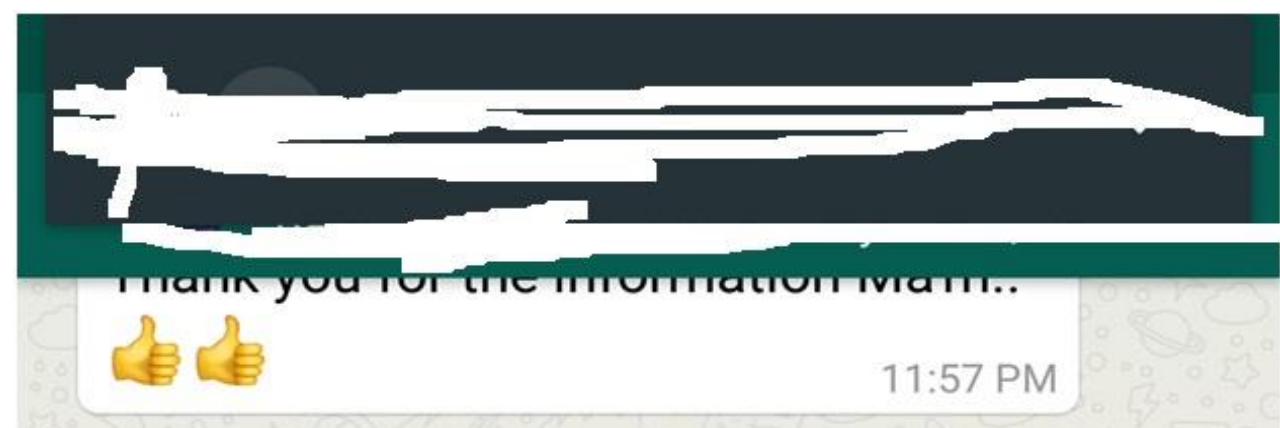

\section{SEPTEMBER 2017}
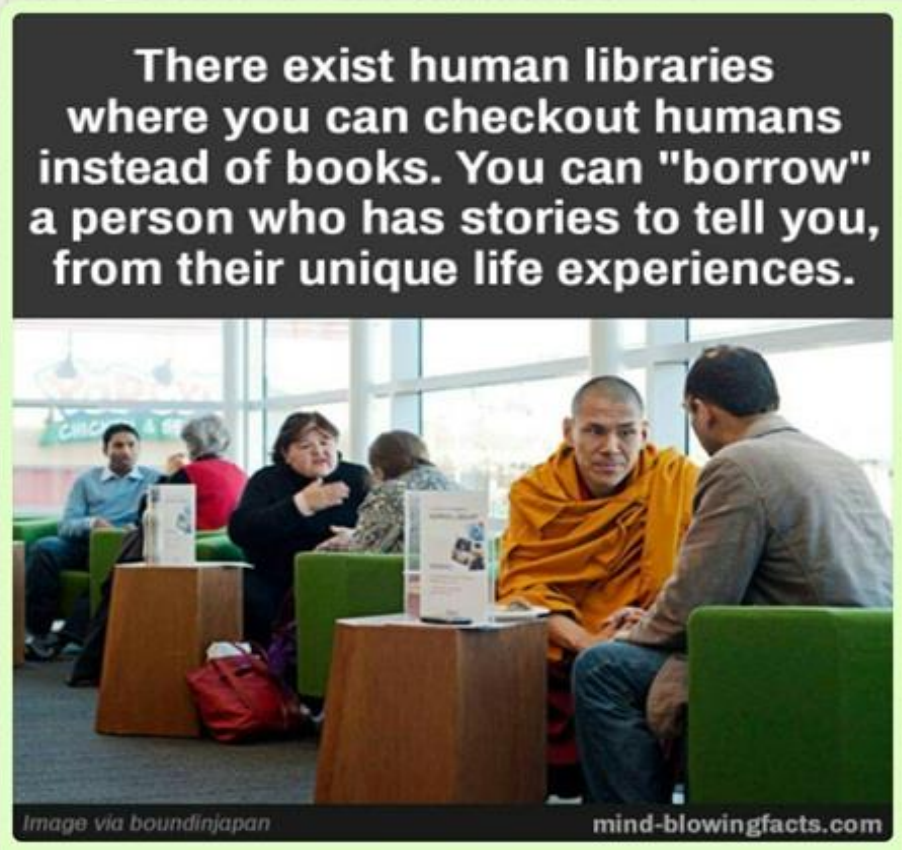

Human beings as sources of information

\section{Good idea it's unique}

3:55 PM

\section{SEPTEMBER 2017}

\section{:) |ype a message}
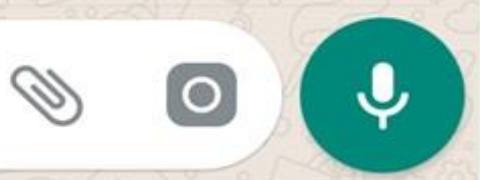

Figure 5: Sharing Links 


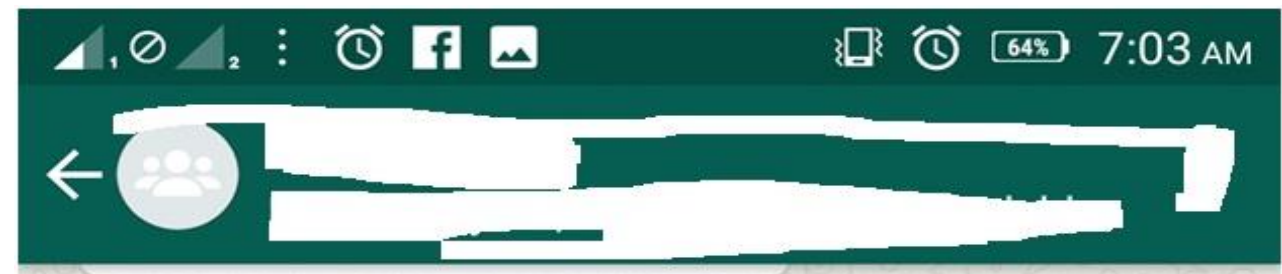

17 OCTOBER 2017

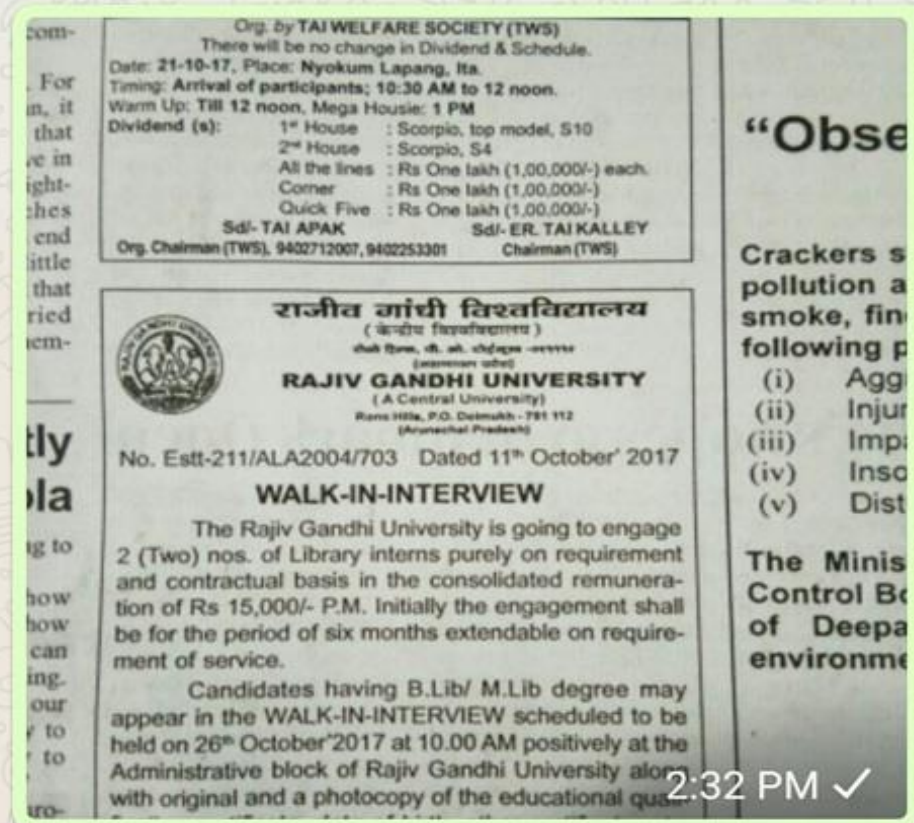

\section{OCTOBER 2017}

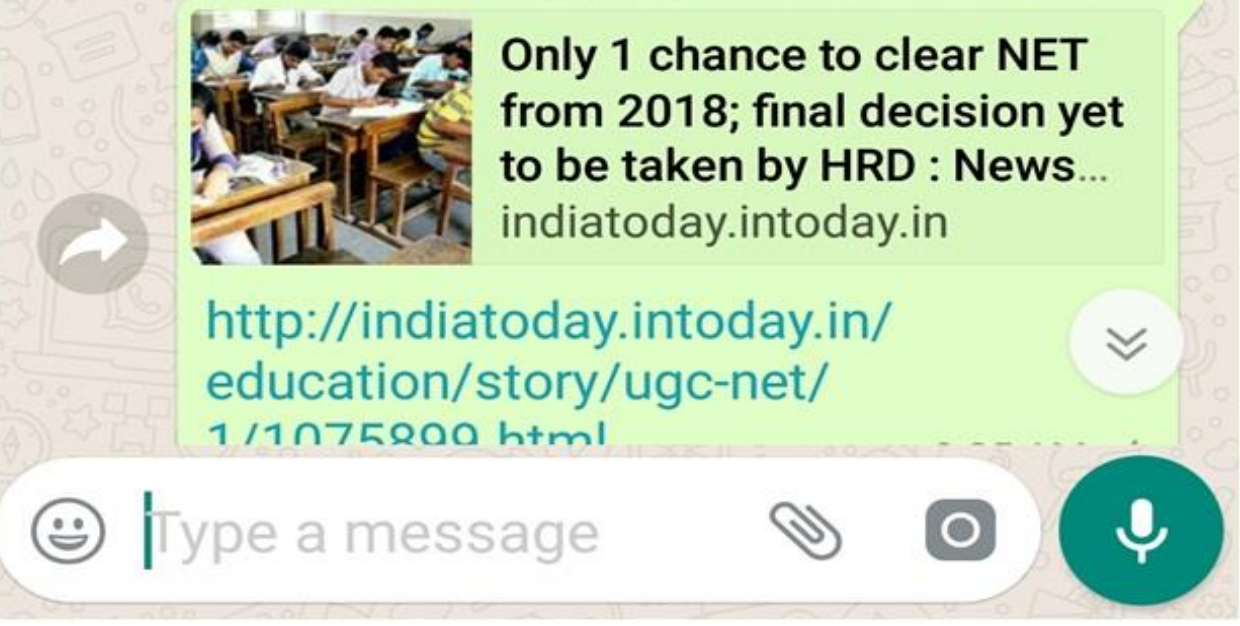

Figure 6: Sharing News Links 


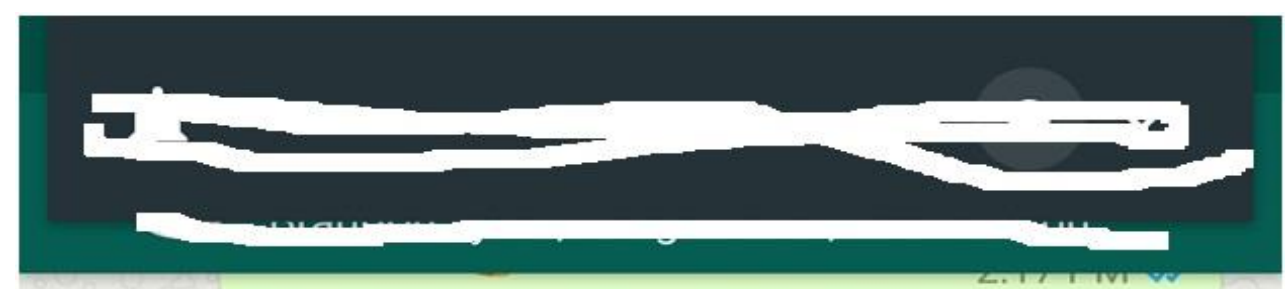

LPU student dies, friend hurt in attack by neighbours over playing loud music...

www.tribuneindia.com

http://www.tribuneindia.com/mobi/

news/punjab/lpu-student-dies-inattack-by-neighbours-over-playingloud-music/510131.html

๑. Tragic. But I believe both parties were wrong. I also complain to the rangbah dong about my neighbour $\mathrm{s}$ loud music. Especially after 10pm

But they shouldn't have taken matters into their own hands...

10 DECEMBER 2017

:) |'ype a message
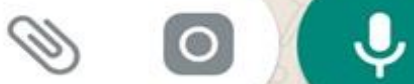

Figure 7: Discussing a News Item 


\section{Types of responses to posts}

As far as responses are concerned, many posts evoke a variety of responses such as emojis, GIFs and comments. Some posts don't evoke any response at all.. One of the most significant categories of information are the queries asked on various aspects of the subject taught in the classroom. The replies to the queries asked could be useful to both the enquirer, to other members of the group, as also to the non-members of the group who might browse the page.

7. Frequency of sharing of information (on an average) - The frequency varies amongst the groups, some groups being more active than others. On an average, information is shared twice a week. The groups come alive especially before busy periods like examination time, starting and ending of internship, and after results where students ask for advice from the teacher and from each other and discussions may follow.

\section{Objectives of the Study:}

The study was interested in exploring the type of information shared on four Whatsapp groups of the Department of Library and Information Science (DLIS), NEHU With this in mind two objectives were framed:

1. To identify the categories of information shared in Whatsapp groups of DLIS, NEHU

2. To explore the significance of such information to university students

\section{Methodology:}

An Online questionnaire was applied in all four Whatsapp groups. Six structured questions and one open ended question were put up for responses. Instructions on how to answer the questions were given.

\section{Timeframe}

The researcher studied the information shared since the inception of these groups. 
11. Results - The study garnered the following quantitative results :

Table 1. Population (Total number of members)

\begin{tabular}{|l|l|}
\hline $\begin{array}{l}\text { 1st } \\
\text { Semester } \\
\text { MLibSc }\end{array}$ & 27 \\
\hline $\begin{array}{l}\text { 3rd } \\
\text { Semester } \\
\text { MLibSc }\end{array}$ & 28 \\
\hline Interns & 28 \\
\hline $\begin{array}{l}\text { Phd } \\
\text { Scholars }\end{array}$ & 5 \\
\hline
\end{tabular}

Table 2. Response Rate

\begin{tabular}{|l|l|}
\hline $\begin{array}{l}\text { 1st } \\
\text { Semester } \\
\text { MLibSc }\end{array}$ & $18(67 \%)$ \\
\hline $\begin{array}{l}\text { 3rd } \\
\text { Semester } \\
\text { MLibSc }\end{array}$ & $\begin{array}{l}13 \\
(46.42 \%)\end{array}$ \\
\hline Interns & $14(50 \%)$ \\
\hline $\begin{array}{l}\text { Phd } \\
\text { Scholars }\end{array}$ & $3(60 \%)$ \\
\hline
\end{tabular}

Table 3. What is your opinion on having a Whatsapp group for this particular paper?

\begin{tabular}{|l|l|l|l|}
\hline GROUP & $\begin{array}{l}\text { 1a. It is } \\
\text { a good } \\
\text { initiative }\end{array}$ & $\begin{array}{l}\text { 1b. It is } \\
\text { unnecessary }\end{array}$ & $\begin{array}{l}\text { 1c. Any } \\
\text { other } \\
\text { opinions? }\end{array}$ \\
\hline $\begin{array}{l}\text { 1st } \\
\text { Semester } \\
\text { MLibSc }\end{array}$ & $\begin{array}{l}18 \\
(100 \%)\end{array}$ & & \\
\hline $\begin{array}{l}\text { 3rd } \\
\text { Semester } \\
\text { MLibSc }\end{array}$ & $\begin{array}{l}13 \\
(100 \%)\end{array}$ & & \\
\hline Interns & $\begin{array}{l}14 \\
(100 \%)\end{array}$ & & \\
\hline $\begin{array}{l}\text { Phd } \\
\text { Scholars }\end{array}$ & $3(100 \%)$ & & \\
\hline
\end{tabular}


Table 4. Which part of the group content do you find most useful?

\begin{tabular}{|l|l|l|l|l|l|}
\hline GROUP & $\begin{array}{l}\text { 2a.Information } \\
\text { (discussions, } \\
\text { links, etc.) on } \\
\text { the paper }\end{array}$ & $\begin{array}{l}\text { 2b. } \\
\text { Information } \\
\text { on the } \\
\text { Library } \\
\text { Profession } \\
\text { in general }\end{array}$ & $\begin{array}{l}\text { 2c. } \\
\text { Chats }\end{array}$ & $\begin{array}{l}\text { 2d. } \\
\text { News } \begin{array}{r}\text { General and } \\
\text { announcements }\end{array}\end{array}$ & $\begin{array}{l}\text { 2e. All } \\
\text { parts }\end{array}$ \\
\hline $\begin{array}{l}\text { 1st } \\
\text { Semester } \\
\text { MLibSc }\end{array}$ & & & & & \\
\hline $\begin{array}{l}\text { 3rd } \\
\text { Semester } \\
\text { MLibSc }\end{array}$ & & & & & 10 \\
\hline Interns & & & & $(77 \%)$ \\
\hline $\begin{array}{l}\text { Phd } \\
\text { Scholars }\end{array}$ & & & & $13(93 \%)$ \\
\hline
\end{tabular}

Table 5. Benefits of the Group. The Group has :

\begin{tabular}{|c|c|c|c|c|c|c|c|}
\hline GROUP & $\begin{array}{l}\text { 3a. } \\
\text { Raise } \\
\text { d the } \\
\text { clarity } \\
\text { on the } \\
\text { subje } \\
\text { ct }\end{array}$ & $\begin{array}{l}\text { 3b. } \\
\text { Raise } \\
d \text { the } \\
\text { intere } \\
\text { st } \\
\text { level } \\
\text { in the } \\
\text { subjec } \\
t\end{array}$ & $\begin{array}{l}\text { 3c. } \\
\text { Updated } \\
\text { the } \\
\text { knowledg } \\
\text { e on the } \\
\text { subject }\end{array}$ & $\begin{array}{l}\text { 3d. } \\
\text { Increase } \\
\text { d the } \\
\text { interactio } \\
n \\
\text { between } \\
\text { the } \\
\text { teacher } \\
\text { and the } \\
\text { students }\end{array}$ & \begin{tabular}{|l} 
3e. \\
Increase \\
d the \\
interactio \\
n among \\
the \\
student
\end{tabular} & $\begin{array}{l}\text { 3f. } \\
\text { Created } \\
\text { a sense } \\
\text { of } \\
\text { belongin } \\
\text { g }\end{array}$ & $\begin{array}{l}\text { 3g. All of } \\
\text { the } \\
\text { above }\end{array}$ \\
\hline $\begin{array}{l}\text { 1st } \\
\text { Semest } \\
\text { er } \\
\text { MLibSc }\end{array}$ & & & & & & & $5(28 \%)$ \\
\hline $\begin{array}{l}\text { 3rd } \\
\text { Semest } \\
\text { er } \\
\text { MLibSc }\end{array}$ & & & & & & & 10 (77\%) \\
\hline Interns & & & & & & & $\begin{array}{l}10(71.42 \\
\%)\end{array}$ \\
\hline $\begin{array}{l}\text { Phd } \\
\text { Scholar } \\
\text { s }\end{array}$ & & & & & & & $2(67 \%)$ \\
\hline
\end{tabular}


Table 6. What are the instructional uses of this group?

\begin{tabular}{|l|l|l|l|l|l|}
\hline GROUP & $\begin{array}{l}\text { 4a. Easier } \\
\text { accessibility } \\
\text { to learning } \\
\text { materials }\end{array}$ & $\begin{array}{l}\text { 4b. } \\
\text { Teacher } \\
\text { availability }\end{array}$ & $\begin{array}{l}\text { 4c. } \\
\text { Learning } \\
\text { anytime, } \\
\text { anywhere }\end{array}$ & $\begin{array}{l}\text { 4d. } \\
\text { Possibility } \\
\text { for } \\
\text { clearing } \\
\text { doubts } \\
\text { and } \\
\text { correcting } \\
\text { mistakes }\end{array}$ & $\begin{array}{l}\text { 4e. All } \\
\text { of the } \\
\text { above }\end{array}$ \\
\hline $\begin{array}{l}\text { 1st } \\
\text { Semester } \\
\text { MLibSc }\end{array}$ & & & 2 & $4(22.22 \%)$ & $12(67 \%)$ \\
\hline $\begin{array}{l}\text { 3rd } \\
\text { Semester } \\
\text { MLibSc }\end{array}$ & & & $(11.11 \%)$ & & $\begin{array}{l}12 \\
(92.30 \%)\end{array}$ \\
\hline $\begin{array}{l}\text { Interns } \\
\text { Shd }\end{array}$ & & & $1(7.14 \%)$ & $4(29 \%)$ & $\begin{array}{l}9 \\
(64.28 \%)\end{array}$ \\
\hline $\begin{array}{l}\text { Scholars } \\
\text { Shd }\end{array}$ & & & & & $3(100 \%)$ \\
\hline
\end{tabular}

Table 7. What problem have you faced using this group?

\begin{tabular}{|l|l|l|l|}
\hline GROUP & $\begin{array}{l}\text { 5a. Time } \\
\text { consuming }\end{array}$ & $\begin{array}{l}\text { 5b. } \\
\text { Expensive } \\
\text { to use } \\
\text { regularly }\end{array}$ & $\begin{array}{l}\text { 5c. } \\
\text { Inappropriate } \\
\text { content }\end{array}$ \\
\hline $\begin{array}{l}\text { Semester } \\
\text { MLibSc }\end{array}$ & & & \\
\hline $\begin{array}{l}\text { 3rd } \\
\text { Semester } \\
\text { MLibSc }\end{array}$ & & & \\
\hline Interns & & & \\
\hline $\begin{array}{l}\text { Phd } \\
\text { Scholars }\end{array}$ & $1(33.33 \%)$ & & \\
\hline
\end{tabular}

12. Findings : Based on the data above, the following information summarizes the results of the study: 


\subsection{Response Rate}

The $1^{\text {st }}$ Semester $(67 \%)$ and $\mathrm{PhD}(60 \%)$ groups record higher percentages of responses compared to the $3^{\text {rd }}$ Semester $(46.42 \%)$ and Interns (50\%) groups. Overall the response rate is not fully satisfactory. This can be attributed mainly to the questionnaire being administered during vacations since otherwise members of all groups are fairly active.

\subsection{Is having a Whatsapp group worth it?}

All groups have responded with 100\% Yays. Enough Said

12.3 Are the Group's offerings satisfactory? (Which part of the group content do you find most useful?) The types of offerings on the groups range from discussions and links on the specific paper, to chats, announcements and greetings. The members on all groups seem to be satisfied with all parts of their respective groups responding positively (between $77 \%$ and $93 \%$ ) to the offerings on their plate

\subsection{Benefits of the Group}

The activities in the groups have not only brought clarity on the subject and increased interaction amongst their members, they are fostering an overall sense of belonging as is evident from the positive response (between $67 \%$ and $77 \%$ ).

\subsection{Whatsapp groups as supplementary teaching tools}

The positive responses to the instructional uses of the Whatsapp groups under study are evidence of their usefulness as supplementary teaching tools. The members have testified to the groups' uses in bringing clarity on the subject as well as in clearing doubts, with the added benefit of 'learning anytime, anywhere.'

\subsection{Problems with Whatsapp groups?}

Clearly the Whatsapp groups under study are more boon than bane as is evident from the respondents' rejection of there being any problems with the groups. Only one respondent (PhD scholar) found the Whatsapp exercise time consuming.

\section{QUALITATIVE DATA}

Opinions presented as is (verbatim) 


\section{$1^{\text {st }}$ Semester M.Lib NEHU -}

1. The group increased in sharing \& retrieving ideas, knowledge and any kind of information. The group has been an overall helpful experience to everyone in increasing their knowledge.

2. We can communicate, ask question anywhere, any place outside classroom.

\section{Third Semester MlibSc}

1. Having Whatsapp group is effective especially when you have doubts regarding the subject. At the same time through this group we can have other useful information which is necessary for us to develop our knowledge and skills.

2. It help one to open up. It creates a channel to gather information

3. Whatsapp group is effective. We can share any impt updates. Learning and teaching anytime anywer is possible with whatsapp groups

4. Whatsapp group has help us in sharing and getting information

5. It helps us to interact and share information with each other

6. It enhances our IQ.

7. Whatsapp group it give information anytime and it helps to interact more

8. The group is very effective as it helps us to be interactive and we can clarify our doubts anytime

9. It increases more interaction \& having Whatsapp group is a nice experience so far

10. It helps us interact and discuss anything and it helps to clear our doubts anytime and we get to learn and share information.

11. Having a Whatsapp group helps us in getting information from other group members related to anything that is useful. It acts as an overall source of information. It also helps in clarifying our doubts related to the subject anytime and anywhere 


\section{Suggestions (presented as is)}

\section{$3^{\text {rd }}$ Semester MLibSc}

1. This group is very productive $\mathrm{n}$ should be continue....as we will learn more from this group

2. This group should be continued as it helps us gather information.

\section{PhD Scholars}

1. Subject specific.

2. Make all group members as administrator

3. Every participants contribute

\section{Conclusion}

Results of the study are testimony that there is great potential for using social media like Whatsapp and Facebook groups as supplementary teaching tools in higher education. The type of information shared in these groups is diverse, ranging from academic and professional, to news and counseling. The responses and discussions are quite mature. Members receive information that may not be available in other forums and at a quicker pace too. There is also the 'learning anytime, anywhere,' advantage. While the traditional chalk, blackboard and lecture methods continue to be relevant at all levels of education, the potential of social media needs exploring particularly in a field like Library and Information Science. All it takes is dedicated and dynamic teachers to initiate and maintain such groups.

\section{References}

Bouhnik, D., \& Deshen, M. (2014). WhatsApp goes to school: Mobile instant messaging between teachers and students. Journal of Information Technology Education: Research, 13, 217-231. Retrieved from http://www.jite.org/documents/Vol13/JITEv13ResearchP217-231Bouhnik0601.pdf

Calvo, R., Arbiol, A., \& Iglesias, A. (2014). Are all chats suitable for learning purposes? A study of the required characteristics. Procedia Computer Science, 27, 251-260. 
Cifuentes, O. E., \& Lents, N. H. (2011). Increasing student-teacher interactions at an urban commuter campus through instant messaging and online office hours. Electronic Journal of Science Education, 14(1).

Doering, A., Lewis, C., Veletsianos, G., \& Nichols-Besel, K. (2008). Preservice teachers' perceptions of instant messaging in two educational contexts. Journal of Computing in Teacher Education, 25(1), 512.

Smit, I. (2012). WhatsApp with BlackBerry; Can Messengers (BBM) be MXit?. In Proceedings of the 14th Annual Conference on World Wide Web Applications. Cape Peninsula University of Technology, Cape Town, South Africa.

Sweeny, S. M. (2010). Writing for the instant messaging and text messaging generation: Using new literacies to support writing instruction. Journal of Adolescent \& Adult Literacy, 54(2), 121-130. 